Web Jurnal Online: jurnal.unmuhjember.ac.id

By: Rio Yusri M; Faizah Bafadhal; Serli Agnes; Putri Andayani; Nahdatun Nisa Strengthening Collaborative Government In The Open Government Era Based On The

Utilization Of E-Government In Jambi Province

\title{
STRENGTHENING COLLABORATIVE GOVERNMENT IN THE OPEN GOVERNMENT ERA \\ BASED ON THE UTILIZATION OF E-GOVERNMENT IN JAMBI PROVINCE
}

\author{
Rio Yusri Maulana ${ }^{\mathrm{a}}$, Faizah Bafadhal ${ }^{\mathrm{b}}$, Serli Agnes Perwirawati Natalia Napo ${ }^{\mathrm{c}}$, \\ Putri Andayani Br. Sitepu ${ }^{\mathrm{d}}$, Nahdatun Nisa Mubai ${ }^{\mathrm{e}}$. \\ a,b,c,de Program Studi Ilmu Pemerintahan, Fakultas Ilmu Sosial dan Ilmu Politik, \\ Universitas Jambi \\ e-mail : rioyusrimaulana@unja.ac.id
}

\begin{abstract}
The enactment of Law No. 14/2008 concerning Public Information Openness and Law No. 25/2009 on Public Services is the legal basis for the existence of Open Government Indonesia (OGI), which should be applied by all government hierarchies in Indonesia. In the OGI action plan there are four main things; increasing public participation, improving governance through bureaucratic reform, strengthening public services, strengthening public information disclosure and data governance. The implementation of the Open Government administration should be supported by the use of e-government, in Jambi Province, this has not fully gone according to expectations even though it has long been a discourse. Public services are made easy and cheap with the presence of applications such as e-Planning and e-Budgeting which are products of e-government, gradually implemented by the Government of Jambi Province. Basically the challenges in implementing e-government are at the policy level, financial support and infrastructure. On the other hand, the system and the range of authorities that have not been integrated are still difficult obstacles to be parsed. This article examines more deeply the strengthening of government collaboration in the utilization of e-government applications by referring to the development of governance with the Open Government concept and this is a consequence arising from the granting of regional autonomy, it is necessary to adjust institutional arrangements and patterns of relations between government institutions and communities .
\end{abstract}

Keywords: Government Collaboration, Service Innovation, Open Government, e-government, Data Governance. 


\section{INTRODUCTION}

Open Government Design or internationally known as Open government, this concept became popular after the Memorandum on Transparency and Open Government by the Barack Obama Administration in the United States in 2009, and was followed by the launch of data.gov.uk by the British government in 2010. Then this concept of openness triggered a movement that followed globally, the emergence of a government data portal that continued to spread, created by the government and multilateral independent teams in collaboration with the government working to develop open government data in a country ${ }^{1}$. Wirtz and Birkmeyer (2015: 12) define open government as a multilateral, political and social process, which includes particular transparent, collaborative and participatory action by government and administration. (Obama, 2009). In Indonesia, the open government movement has been responded by the Indonesian government through Open Government Indonesia (OGI) which has been rolling since 2011 both in the central government and regional government. The OGI movement was born from a similar movement called the Open Government Partnership. OGP is a multilateral initiative that aims to guarantee the government's concrete commitment to increase transparency, empower people, fight corruption, and use new technology to strengthen the government. OGP was officially established on September 20, 2011 by eight countries, namely Brazil, Indonesia, Mexico, Norway, the Philippines, South Africa, Britain and the United States. The founding countries declared the Open Government Partnership (OGP) movement and approved and announced action plans carried out by each country. Currently OGP membership is sixty-four countries, including hundreds of community organizations in it. Even Indonesia as one of the OGP Co-Chairs for the period October 2013 - September 2014. The vision of OGP is to create more governments that are more transparent, responsible and responsive to society on an ongoing basis, with the main goal being to improve the quality of government and the quality of public services received by the community. This requires an effort to change norms and culture so that it can ensure collaboration between the government and civil society ${ }^{2}$.

In general, Open Government Indonesia (OGI) allows a communication channel that is not only two-way between the government and the community but also interactive and even real-time (real-time computing can be directly observed and responded to). Various channels (communication channels) as a manifestation of more open government can be observed in social networks and integrated public service portals for the community, although not yet can be enjoyed by all levels of Indonesian society, the presence of OGI as an effort to see the impact of government policy with the issuance of Law No. 12 of 2008 concerning Public Information Openness which has been effective since 2010.

Open Government is a movement to produce more participatory and more innovative management including at the level of regional government, this is based on Law No. 37/2008 concerning the Ombudsman of the Republic of Indonesia, Law No. 25/2009 on Public Services, Permendagri 35/2010 concerning Management Guidelines Information in the Ministry of Home

\footnotetext{
${ }^{1}$ Wirtz, B. W., Weyerer, J. C., \& Rosch, M. (2017). Citizen and open government: An empirical analysis of antecedents of open government data. International Journal of Public Administration, 00(0), 1-14. doi:10.1080/01900692.2016.1263659

${ }^{2}$ Laporan Akhir Reviu Implementasi Open Government Indonesia (2011-2014), Direktorat Politik dan Komunikasi Kementerian Perencanaan Pembangunan Nasional / BAPPENAS, 2015.
} 
Proceeding ICOGISS 2019

Page: 401-413 ISBN: 978-602-6 988-75-1

Web Jurnal Online: jurnal.unmuhjember.ac.id

By: Rio Yusri M; Faizah Bafadhal; Serli Agnes; Putri Andayani; Nahdatun Nisa Strengthening Collaborative Government In The Open Government Era Based On The

Utilization Of E-Government In Jambi Province

Affairs and Regional Government, as well as Government Regulations or PP 61/2010 concerning Implementation of Law 14/2008.

The Open Government harmony is supported by the implementation of electronic-based governance, or what is commonly called e-government, before the presence of the OGI movement, the innovation of governance in Indonesia was preceded by the development of egovernment which had been initiated since 2003. for an integrated system, the development of e-government in Indonesia is also supported by the Instruction of the President of the Republic of Indonesia No. 3/2003 concerning National e-government Development Policy and Strategy. In this regard, this is in line with the spirit of bureaucratic reform in Indonesia, e-government increasingly plays a role in improving the quality of public services and helping the process of delivering information more effectively to the public. It needs to be realized and understood that according to the mandate of the Constitution or UUD 1945 Article 18 Paragraph (2) and Article 34 paragraph (3), improving public services must get the main attention from the government, because public services are social rights or fundamental rights ${ }^{3}$.

The author looks at how the implementation of e-government and Open Government at the regional government level, analyzes the conditions of public service provision and collaboration between government institutions, the Jambi Provincial Government along with the Regional Representatives Council (DPRD) of Jambi Province have ratified Jambi Province Regional Regulation No. 3 of 2014 regarding the Public Information Service for the Implementation of Regional Government on 11 March 2014 by looking at the goals and objectives of the Regional Regulation to realize good local government implementation, through openness, participation, effective and efficient, accountable and accountable and encourage and increase community participation in policy making public and good management of public bodies in the framework of open government.,However, in 2015 Jambi Province was still at a fairly low level of openness, which was ranked 28th out of 34 provinces in Indonesia, compared to several provinces such as DKI Jakarta, West Java, North Sumatra, and Riau. from this data Jambi Province is still lagging quite significantly, the comparison can be seen from the table below:

Table 1. Comparison of Rating Crosses Elements of Openness in the Indonesian Provincial Government in $2015^{4}$

\begin{tabular}{|l|l|l|l|l|l|}
\hline No & Province & $\begin{array}{l}\text { Local } \\
\text { Government } \\
\text { Performance } \\
\text { Evaluation }\end{array}$ & $\begin{array}{l}\text { Compliance } \\
\text { with Public } \\
\text { Services }\end{array}$ & $\begin{array}{l}\text { Performance } \\
\text { Accountability }\end{array}$ & Total \\
\hline 1. & North Sumatra Province & 2,6885 & 75,54 & 58,00 & 136,2285 \\
\hline 2. & West Java Province & 0,1760 & 52,72 & 70,06 & 122,9560 \\
\hline 3. & Jakarta Province & 3,0560 & 61,20 & 58,57 & 122,8260 \\
\hline 4. & Riau Province & N/A & 57,05 & 54,73 & 111,7800 \\
\hline 5. & Jambi Province & 2,6228 & 28,12 & 52,87 & 83,6267 \\
\hline
\end{tabular}

\footnotetext{
3 Elysia V., dkk., (2017) Implementasi E-Government untuk Mendorong Pelayanan Publik yang Terintegrasi Di Indonesia . Optimalisasi Peran Sains dan Teknologi untuk Mewujudkan Smart City.

${ }^{4}$ Laporan Kegiatan Koordinasi Pelaksanaan Rencana Aksi Keterbukaan Pemerintah (Open Government Indonesia 2016-2017)
} 
The Jambi Provincial Government is one of the regional governments that has also utilized information technology in the administration of government, but its implementation has experienced various challenges that have caused delays, this can be seen from the fact that the Jambi Provincial Government is trying more seriously in integrating e-government in the planning and budgeting system starting in 2018. The development of the use of e-government in Jambi Province It can be seen from the follow up of the implementation of government planning and budgeting with the use of e-government based on e-Planning and e-Budgeting, this action is a recommendation from the Corruption Eradication Commission (KPK) to all provincial governments in Indonesia As stated in the regional action plan for using the e-planning and ebudgeting system, the Jambi Provincial Government cooperates with the Government of North Sumatra Province in a Memorandum of Understanding (MoU), in the form of a 4-day Training of Trainers for application management operators in Jambi Provincial Government.

The issue of the slow response of the Jambi provincial government in developing egovernment, indicated the existence of several underlying problems, such as the low commitment given by public officials, the inconsistency in the application of regulations that regulate the integration of authority between government agencies in providing services, so that collaboration towards innovation is not directed, hampered and stagnant, lacking commitment to financial availability, low quality of human resources who have expertise in the field of IT development, and work culture is still not supported.

\section{LITERATURE REVIEW Open Government (OG).}

The Organization for Economic Co-operation and Development (OECD) defines Open Government as "transparency of government actions, access to services and information from the government, and government responsiveness to new ideas, requests, and needs." Open Government policies are a means of achieving improving the quality of democracy in a country to improve the fulfillment of people's needs through an open policy management. This policy produces a variety of benefits for the business world and citizens, including for governments that implement it the policy. Key examples of the above policies include:

1. Ensuring better policy outcomes

2. Improve policy efficiency and effectiveness

3. Improve compliance with policies and regulations

4. Encouraging inclusive socio-economic development

5. Foster innovation

The Organization for Economic Co-Operations and Development (OECD) presents a concept that contains a broader understanding, namely by using the term open government. The concept of government openness according to the OECD is not just to be transparent, but also includes aspects of accessibility and responsiveness within relations between the government and the citizens it serves. Transparency in the sense that every government action can be observed by the public; accessible in the sense that each government action can be known by everyone, at any time, and everywhere; and responsive to new public ideas and needs (OECD, 2015). Thus, the open government here is interpreted as the administration of government carried out transparently and involving citizens and stakeholders since decision making, implementation up to evaluation. 
Open government according to Global Integrity (Turner, 2015) includes three things, namely information transparency, public involvement and accountability. Through transparency, the public understands how the government works. With public involvement, the public can influence the way their government works by being involved in government policy processes and service delivery programs. Accountability means that the public can ask the government to account for the performance of its policies and services. These three elements explain that open government initiatives, programs and interventions are often referred to as "Open Government". The most important thing here, is that none of the initiatives or interventions of open government can stand alone. If it is combined with one another, it will truly look at the potential of open government in its most powerful and holistic form.

The concept of $e$-Government (e-Gov).

E-Government or Electronic Government is one form or model of a government system based on the power of digital technology, where all administrative work, service to the community, supervision and control of resources belonging to the organization concerned, finance, taxes, levies, employees and so on are controlled in one system . E-Government is a new development in order to improve public services based on the utilization of information and communication technology so that public services become more transparent, accountable, effective and efficient. In order to improve the quality of government services, it is necessary to integrate agency business processes into information systems that create efficiency and effectiveness in services. The implementation of e-Government in local governments is also one of the efforts to create transparency and improve public services to answer the needs of bureaucracy and administration in local governments. Development of information systems can also improve decision-making related to regional development planning. The mechanism of the relationship is through the use of information technology which is collaboration or merging between computers and communication network systems. Budi Rianto et al (2012: 39) say there are at least four indicators the success of E-Government, namely:

1. Availability of data and information in the data center.

2. Availability of data and information for regional promotion needs.

3. Availability of E-Government applications supporting office work in public services.

4. Availability of application of public dialogue in order to improve communication between governments, between the government and the private sector and the community through e-mail, SMS or teleconference applications .

The strategy in the innovation of public service provision, according to Denis Anderson, et al. (2015: 14-15) is the government's efforts to be able to provide public services in a way that is fair, effective, inclusive-centered on citizens, and the public sector that has the capacity to provide services, needs to be strengthened at the central and regional levels. This means efforts are needed to strengthen the four main dimensions between the public sectors, namely; public institutions especially at the regional level to provide services; leadership capacity and human resources needed to provide services in a transparent, fair, efficient and accountable manner; processes and mechanisms that support citizen participation in the design and delivery of services; and organizational culture so that it can create space for continuous improvement and innovation in service delivery to the community. 1

Denis Anderson, et al. (2015: 14-15) propose five main strategies in providing public services: 
Web Jurnal Online: jurnal.unmuhjember.ac.id

By: Rio Yusri M; Faizah Bafadhal; Serli Agnes; Putri Andayani; Nahdatun Nisa Strengthening Collaborative Government In The Open Government Era Based On The

Utilization Of E-Government In Jambi Province

1. Innovative transformation of leadership and public public officials'capacities

2. Institutional and organizational innovation.

3. Process innovation, including innovative channels and mechanisms for partnership building and citizen engagement .

4. Organizational culture to promote knowledge sharing and management for innovation, transparency and accountability.

5. Leveraging the potential of ICTs: new opportunities for innovation .

The five strategies above are interrelated and interdependent, therefore, this strategy must be used holistically. In other words, this strategy is important to be discussed and studied in an integrated manner in strengthening institutional frameworks, processes and mechanisms to provide services fairly and effectively, developing human resource capacity for equitable service delivery and the development and use of technology.

\section{METHOD}

This research was conducted using a qualitative approach emphasizing the analysis of quality. The data collected is not in the form of quantification of numbers, passing the data obtained comes from in-depth interviews, researcher field notes, personal documents, and other official documents obtained through field research. So that the main target of this research is to describe the empirical relationship behind phenomena by obtaining a deep, thorough, detailed and complete meaning. Therefore the use of a qualitative approach in this study is to match, compare, and look for the red thread between empirical reality and the prevailing theory using descriptive methods. Data was collected through library research and documentation, observation and in-depth interviews with a number of informants consisting of elements of local government and other non-governmental organizations such as the media and NGOs related to their respective main tasks and functions.

\section{DISCUSSION}

\section{Transformation of Innovation in Local Government Information Systems}

Transformation of e-government innovation can be seen $\mathrm{d}$ ari overall number of Local Government comprising 548 provinces and districts / cities in Indonesia were recorded, 543 of which has recorded the official website using the domain go.id. of the total number of 483 websites accessible to the community, and the remaining 60 local governments cannot be accessed due to various problems. This means that from these data, there are around 88\% of provincial and district/city government websites that have websites that can be accessed. More is explained in the table below : 
Proceeding ICOGISS 2019

Page: 401-413 ISBN: 978-602-6 988-75-1

Web Jurnal Online: jurnal.unmuhjember.ac.id

By: Rio Yusri M; Faizah Bafadhal; Serli Agnes; Putri Andayani; Nahdatun Nisa Strengthening Collaborative Government In The Open Government Era Based On The

Utilization Of E-Government In Jambi Province

Table 2. Distribution of the number and status of provincial and district government websites ${ }^{5}$.

\begin{tabular}{|l|l|l|}
\hline Status & Number of websites & Percentage \\
\hline Accessible & 483 & $88 \%$ \\
\hline Not accessible & 60 & $11 \%$ \\
\hline Don't have a website & 5 & $1 \%$ \\
\hline Total & 548 & $100 \%$ \\
\hline
\end{tabular}

From the data above, it can be seen that the development of e-government, which leads to a fairly good development nationally, transforms this innovation along with the development of e-governmentin Indonesia in the early stages starting with the issuance of Presidential Instruction No. 3 of 2003, which mandates 4 models of stages of $e$ government implementation. Explained in the Presidential Instruction that e-government development is carried out through 4 levels: (1) preparation, (2) maturation, (3) consolidation, and (4) utilization. Condition of information channel e-government at the outset of its development in Indonesia, the quantitatively good conditions above are not relevant to the development of stages which are still largely in the first stage (preparation), only a small proportion have reached the second level (maturation), and no one has even those who reach the third level (stabilization) and / or fourth level (utilization).

Table 3. the latest status classification of developments in e-government in Indonesia by province in $2018^{6}$

\begin{tabular}{|l|l|l|l|l|l|l|l|}
\hline No. & \multirow{2}{*}{ Province } & \multirow{2}{*}{$\begin{array}{c}\text { Number of } \\
\text { Regional } \\
\end{array}$} & & & \multicolumn{5}{|c|}{ Stages according to Presidential Instruction No. 3 of } \\
\cline { 5 - 8 } & & Governments & Preparation & Maturation & Stabilization & Utilization \\
\hline 1 & Jambi & 12 & 2 & 8 & 2 & - \\
\hline 2 & West Java & 28 & 2 & 17 & 9 & - \\
\hline 3 & DKI Jakarta & 7 & 1 & 5 & 1 & - \\
\hline 4 & $\begin{array}{l}\text { North } \\
\text { Sumatra }\end{array}$ & 43 & 2 & 23 & 7 & - \\
\hline 5 & Riau & 13 & 1 & 5 & 7 & - \\
\hline
\end{tabular}

From the looks that channel information of the website in the local government of Jambi seen from the use of e-government on the use of the website media the general majority is still at the maturation stage, categorized as a website that provides at least one media that presents the interaction of the government with site / public visitors and provides links to other institutions on the internal or external local government itself. The forms of interaction media in question include: providing e-mails, telephone numbers, input forms, polls, discussion forums, sms, and or chat. While only 2 Regional Governments have entered the consolidation stage, or are categorized for websites that provide at least one electronic service in the form of a website or

\footnotetext{
${ }^{5}$ Yunita N.P, Aprianto. R.D, Kondisi Terkini Perkembangan Pelaksanaan E-Government Di Indonesia : Analisis Website, disampaikan pada Seminar Nasional Teknologi Informasi dan Komunikasi, (Yogyakarta, 23-24 Maret 2018).

${ }^{6}$ Ibid
} 
application for accessible public services. Websites or applications are not required to be integrated with one another, enough to enable the public as users to solve government affairs quickly and effectively. The initiative and involvement of local governments in implementing egovernment in Indonesia certainly needs to be appreciated. But being aware of the fact that the mandate of e-government development has been around for the past 15 years, the e-government movement from one stage to another can be considered very slow. This delay is certainly motivated by a variety of contextual reasons: infrastructure, costs, the role of the government, involvement of related parties, etc., must be questioned. Implementation Transformation of $e$ government innovations in Indonesia still faces a number of serious challenges, namely lack of commitment to budget availability, low quality of human resources, low penetration of ICTs, lack of regulatory support, and work culture that is still not supported. Research by Hwang and Syamsuddin shows that the main obstacles to developing e-government are technical difficulties, the existence of digital divide (digital divide) and the lack of willingness to use egovernment from the community and the government itself. ${ }^{7}$

\section{Leadership and Capacity of Human Resources in e-government-based Government Innovation Reform.}

Commitment from the regional head as a leading actor is a major factor in government collaboration in the transformation of innovation in the Jambi Provincial Government, egovernment-based websites and government applications are a means of supporting transparency, accountability and public information transparency, in order to succeed in implementing e-government. commitment from the leadership or in this case the head of the region concerned so that the implementation of e-government does not only follow the trend alone, but must be proven by the presence of the government and felt by the public.

The application of electronic systems and website in this case must really provide significant benefits to the community relating to public information. In relation to the commitment to transparency and openness of public information, the Regional Head or leader must create a government based on the principle of good coporate governance which contains good transparency, accountability and management. All information relating to government performance will be posted via the media website. The commitment of a regional head in realizing transparency and openness of public information in his government is a step to improve the image of the bureaucracy so far that seems rigid and closed. This kind of commitment must be addressed more wisely and well transformed by the ranks of regional institutions so that government programs related to issues of transparency and public information disclosure can be implemented well.

One of the obstacles faced in implementing e-government is the ability of human resources to implement it because it involves how to change the mindset of employees. Therefore to improve the ability of employees to implement e-government in the Jambi Provincial Government through training in information technology. In training and improving human resources, it is necessary to change the view of information and communication technology, not just a tool for managing information, but rather it has cultural aspects.

\footnotetext{
${ }^{7}$ Hwang, J., Syamsuddin, I. (2008). Failure of e-government implementation : A case study of South Sulawesi. In The Third International Conference on Covergence and Hybrid Information Technology, Busan. IEEE Computer Society.
} 
Technology not only requires mastery of hardware, but changes ourselves to interact with the public through information and communication technology. The findings of the research that have been carried out so far are to include employees in e-government development training in the context of technology transfer followed by employees appointed by the Jambi Province Communication and Information Agency, but this kind of training has not involved all regional government institutions (OPD) holistic, not patterned, and still in the preparation stage. Increasing the capacity of my source like this is crucial and it is very important to continue to provide adequate knowledge and skills for all e-government operators throughout the DPO, because the use of applications can be between or across institutions. The training method that needs to be done is to bring qualified and certified trainers, and through training classes that have been adjusted to the needs for current data disclosure, the trainees will be guided and guided step by step to understand, understand and do matters relating to all technologies that will be applied.

In addition the training provided to operators at OPD is carried out by hands-on practice for the training method that is carried out by bringing qualified trainers, and through training classes that have been set up in such a way, the trainees will be guided and guided step by step to understand, understand, and do things related to all technologies that will be applied. In addition, training provided to operators at OPD is done by direct practice (Hands-On) to configure and run existing technologies. The training provided is all application modules, infrastructure, and software used to build information systems in each OPD in accordance with the database requirements that will be used in the OPD. Training is basically to build the capacity and capability of employees so that the execution of tasks can be maximized. But the results of the training provided can be achieved if it is also supported by the ability of human resources to capture and understand what is given in the training. In the implementation of egovernment in Jambi Province, judging from the application and the OPD website, it was shown that in general operators did not yet have adequate capacity to handle e-government in their respective OPDs. For this reason, operator training is very important to continue.

\section{Collaborative Governance and Community Engagement in the Provision of Public Services.}

Global Integrity (Turner, 2015) states that there are three important things in the realization of Open Government namely Collaboration that emphasizes the existence of information transparency, public involvement and accountability. Through transparency, the public understands how the government works. With public engagement, the public can influence the way their government works by being involved in government policy processes and service delivery programs. The author sees that collaboration design seen in the relationship of new forms of e-government use in Jambi Province is still at the Government-to- Government (G-to-G) stage, this can be seen through the completion of government tasks and affairs that connect one government to another, both between agencies, as well as relationships with vertical agencies, jambi Provincial Government has also just implemented the Government to Employees (G-to-E) stage. The G-to-E application type is intended internally for staff in government agencies, which is related to the employee payroll process, employee appraisal, has been done with the application. 
The application of the Open Government principle requires the involvement of the public in accessing services, but this has not been reflected in the use of e-government in the Jambi Provincial Government / Government to Citizens (G-to-C) which should have provided government applications to build and implement various information technology portfolios to interact with the community. In fact, Jambi Province will begin operations in 2019, through the e-planning application system. This allows collaboration and integration of the use of egovernment with the e-Planning application, namely an application for local government planning documents, such as RKPD, KUA PPAS, KUA / PPAS Amendment so that it can be resolved easily, quickly, precisely and in accordance with the directions contained in Permendagri No. 86 of 2016. With the existence of e-planning tools, BAPPEDA can maximize the system and the system is also able to present a very informative analysis for stakeholders including facilitating the public to be involved even from the planning process, accessible on the page http: //eplanning.jambiprov .go.id. ${ }^{8}$

The transformation of innovation can also be seen from the preparation of channels and mechanisms for public involvement in services, including the presence of facilities in the form of infrastructure, without the existence of supporting infrastructure, it is impossible for an electronic-based government to materialize. Availability of adequate information technology infrastructure is $50 \%$ of the key to the successful implementation of e-Government. In Jambi Province, to fulfill infrastructure, government / information and communication services, it is still very difficult to provide adequate infrastructure. This is due to the lack of a given budget. The budget provided by the government is more used to fulfill the activities carried out in the Information and Communication Agency, so the budget is not used to fulfill adequate infrastructure. In this case, it means that the allocation of funds has not focused on the supporting infrastructure requirements for implementing e-government. For that in the future, the government can help allocate sufficient and appropriate funds to provide e-government supporting infrastructure.

${ }^{8}$ Hasil Penelitian, 2018 


\section{CONCLUSSION}

Innovation transformation in the provision of public services in local governments needs to emphasize reforming data governance and patterns of relations between agencies that have implications for strengthening collaboration among government agencies and public access to official government data which ultimately speeds up, simplifies and can reduce costs government service. Furthermore, local governments need to develop a regulatory framework as one of the government's strategies in improving the process of planning, implementing, evaluating and controlling development by ensuring the availability of government data that is accurate, up-to-date and integrated.

The results of the study show that there has not been a clear collaboration design coupled with the low level of understanding among service providers in government regarding mechanisms, methods, and innovation processes that aim to be able to involve the public freely, either as recipients or sources of services. This is due to the lack of commitment from leaders at the elite level, and organizational culture that is still static, not dynamic. And the availability of budget and supporting infrastructure that is still minimal. Then more effective collaboration is needed by being encouraged by improving regulations, structuring and improving the quality of human resources, and commitment to the provision of budgets and supporting infrastructure for electronic-based services. So if all these elements can be fulfilled, the implementation of a government based on open public engagement with open government design can be realized in Jambi Province.

Strong good will and political will are needed to encourage local government leadership commitment in providing flexible budgets in fulfilling the infrastructure and superstructure services, the achievement of government designs that emphasize accountability, transparency, participation, and collaboration which are the main principles of the open government designation ( open government) will be realized. 
Web Jurnal Online: jurnal.unmuhjember.ac.id

By: Rio Yusri M; Faizah Bafadhal; Serli Agnes; Putri Andayani; Nahdatun Nisa Strengthening Collaborative Government In The Open Government Era Based On The

Utilization Of E-Government In Jambi Province

\section{REFERENCES}

Agus Dwiyanto, 2006, Mewujudkan Good Geovernance Melalui Pelayanan Publik. Yogyakarta: UGM Press.

Andhika, L.R., Perbandingan Konsep Tata Kelola Pemerintah: Sound Governance, Dynamic Governance, dan Open Government, Jurnal Ekonomi \& Kebijakan Publik, Vol. 8, No. 2, Desember 2017, hal. $87-102$.

Wirtz, B. W., Weyerer, J. C., \& Rosch, M. (2017). Citizen and open government: An empirical analysis of antecedents of open government data. International Journal of Public Administration, OO(0), 1-14. doi:10.1080/01900692.2016.1263659

Lathrop, Daniel dan Ruma, Laurel. 2010. Open Government: Collaboration, Transparency, and Participation in Practice, California: O’Reilly Media.

Gasco-Hernandez, Mila. 2014. Open Government : Opportunities and Challanges for Public Governance, New York : Springer.

Dennis Anderson, Robert Wu, June-Suh Cho, Katja Schroeder. 2015. E-Government Strategy, ICT and Innovation for Citizen Engagement. Springer : New York.

Hari Sabarno. 2007. Memandu Otonomi Daerah Menjaga Kesatuan Bangsa. Jakarta: Sinar Grafika. Hendytio, Medelina; Alexandra, Lina; Perkasa, Vidhyandika. 2014. Mengkaji Kebijakan Tentang Akses dan Informasi Serta Partisipasi Publik dalam Proses Legislasi: Belajar dari Singapura dan Filipina Serta Rekomendasi Awal Untuk DPR,” dalam CSIS Research, Jakarta: Center for Strategic and International Studies.

Hwang, J., Syamsuddin, I. (2008). Failure of e-government implementation : A case study of South Sulawesi. In The Third International Conference on Covergence and Hybrid Information Technology, Busan. IEEE Computer Society.

Krina L.P.L. 2003. Indikator dan Alat Ukur Prinsip Akuntabilitas, Transparansi dan Partisipasi. Jakarta: Badan Perencanaan Pembangunan Nasional.

Ndraha, Taliziduhu. 2002. Sekilas Ilmu Pemerintahan, Jakarta : BKU Ilmu Pemerintahan Kerjasama IIP-Unpad.

OECD. 2016. Kajian Open Government Indonesia : Hal-Hal Pokok.

Undang-Undang Republik Indonesia Nomor 14 Tahun 2008 tentang "Keterbukaan Informasi Publik," ditetapkan pada 30 April 2008.

Undang-Undang Republik Indonesia Nomor 25 Tahun 2009 tentang "Pelayanan Publik," ditetapkan pada 18 Juli 2009.

Retna, Chitra S. 2013. Independent Reporting Mechanism 2011-2013: Indonesia Progress Report. Washington DC: IRM Open Government Partnership.

Rianto, Budi., Tri Lestari. 2012. Polri \& Aplikasi E-Government dalam Pelayanan Publik. Surabaya : CV. Putra Media Nusantara (PMN).

Sekretariat OGI.2013. OGI Self-Assessment Report Tahun 2012. Jakarta: UKP-PPP. 
Proceeding ICOGISS 2019

Page: 401-413 ISBN: 978-602-6 988-75-1

Web Jurnal Online: jurnal.unmuhjember.ac.id

By: Rio Yusri M; Faizah Bafadhal; Serli Agnes; Putri Andayani; Nahdatun Nisa Strengthening Collaborative Government In The Open Government Era Based On The

Utilization Of E-Government In Jambi Province

Sekretariat OGI.2014. OGI Self-Assessment Report Tahun 2013,” Jakarta: UKP-PPP.

Sekretariat OGI.2015. OGI Self-Assessment Report Tahun 2014. Jakarta: UKP-PPP, 2015.

World Bank, "Pemerintah dan Masyarakat Bekerjasama Mendorong Keterbukaan Data," September $2014 \quad$ (http://www.worldbank.org/in/news/pressrelease/2014/09/05/indonesia-government-and-civil-society-in-partnershiptoencourage-greater-data-transparency)

Yunita N.P, Aprianto. R.D, Kondisi Terkini Perkembangan Pelaksanaan E-Government Di Indonesia : Analisis Website, disampaikan pada Seminar Nasional Teknologi Informasi dan Komunikasi, (Yogyakarta, 23-24 Maret 2018). 